\title{
13
}

\section{Village elections, accountability and income distribution in rural China}

\section{Yang Yao}

Village elections were first envisioned by the late chairman of the National People's Congress (NPC) Peng Zhen as a means to enhance village governance after the commune system was dissolved in China in the early 1980s. In 1987, the NPC passed a tentative version of the Organic Law of the Village Committee (OLVC), and started a 10-year experiment with village elections. In 1998, the NPC formally passed the law and elections quickly spread to the whole country. Since the inception of this system in the mid 1980s, however, controversies regarding the impact of elections on village life have been constant. The institutional environment for elections is by no means friendly. Within the village, the authority of the elected village committee is seriously constrained, if not superseded, by the Communist Party committee. Outside the village, the township and county governments still maintain a heavy hand in village affairs. As a result, even if the elected village committee is willing to advance the interests of the villagers, it might not be able to do so. On the other hand, the decentralised nature of the election might make it easier for local elites to capture local politics, so democracy does not necessarily lead to a fairer provision of public goods (Bardhan and Mookherjee 2005). There is evidence that business élites have begun to dominate elections in some villages (Liu et al. 2001). In addition, lineages are playing a significant role in aligning political interests in many village elections, and people worry that this will distort the results of an election.

Few empirical studies have been devoted to exploring the true performance of village elections. Using survey data from 48 villages for the period from 1986 to 
2002, this chapter provides systematic evidence for the effects of elections in improving accountability and income distribution in the village.

In the literature, evidence suggests that local elections generally increase the responsiveness of local government to its constituency. Foster and Rosenzweg (2001) found that village elections in India led to more investment in road-building instead of irrigation facilities. They interpreted this finding as evidence for a propoor policy as road-building provides jobs for the landless whereas investment in irrigation facilities augments the capacity of landlords. Using data from a quasiexperiment in India in which a group of randomly selected villages was required to elect a woman village head, Chattopadhyay and Duflo (2004) found that the villages with a woman as village head tended to provide more women-friendly public services. Zhang et al. (2004) found in a sample of China's Jiangsu Province that village elections had increased the share of public investment and had no effect on the amount of taxes handed over to the township. Gan et al. (2005a, 2005b) further found that village elections helped to reduce the negative impacts of health shocks on farmers' incomes and strengthened farmers' consumption-smoothing capabilities. Last, Kennedy et al. (2004) found in a sample from Shaanxi Province that, compared with elections with government-appointed candidates, more competitive elections, in which candidates were nominated by villagers, produced village leaders who were more accountable to villagers in decisions regarding land reallocation.

As for the effects of village elections on income inequality, there are two possible ways for elections to play a positive role. One is that democracy leads the government to cater to the interests of the median voter, who generally favours redistribution of income (Alesina and Rodrik 1994; Benabou 1996). The other is that democracy presses the government to spend more to increase the incomes of the poorer portion of the population, on the basis that poverty exerts negative externalities on the richer portion (Gan et al. 2005a). However, existing studies using country-level data have not provided conclusive results. ${ }^{1}$

My data covers a critical period that witnessed a rapid increase in income inequality in rural China. Nationwide, the rural Gini coefficient increased from 0.29 in 1987 to 0.35 in 2000 (Riskin et al. 2002). In the meantime, government investment in the countryside decreased. Using the two-way fixed-effect panel method, we have found several important results. First, the introduction of village elections on average has increased the share of public expenditure in the village government's total expenditure by 4.2 percentage points, which is equivalent to 22.8 per cent of the average share in the sample. Second, it has reduced the share of administrative expenditure by 4 percentage points, equivalent to 18.2 per cent of the sample 
average. To the extent that public expenditure is used to advance the interests of the villagers and administrative expenditure is spent mostly to satisfy the needs of the village leaders, these two results suggest that elections have enhanced the accountability of the village committee.

Third, village elections have not led to more income redistribution; on the contrary, they have reduced the progressiveness of income redistribution. This means that the increased share of public expenditure has been devoted to productive investments since income transfer and investment are the only two components of public expenditure. Last, the introduction of elections, on average, reduces the Gini coefficient in a village by 0.016 , which is equivalent to 5.7 per cent of the sample average and 32 per cent of the growth of the Gini coefficient in the period 1987-2002. Because income redistribution has not increased, this improvement has to be brought about by the village's pro-poor actions, such as increasing productive investments. These results have shown that village elections have worked despite all the constraints imposed on them.

The rest of the chapter is organised as follows. The second section reviews the experiment with village elections in the past 20 years and discusses the factors that might undermine the positive effects of elections. The third section describes the data and presents some descriptive evidence for elections, village expenditure, income redistribution and the Gini coefficient. The fourth section presents the results of the econometric analysis and the fifth section concludes the chapter.

\section{An introduction to village elections in rural China}

The Chinese commune system was dissolved in the early 1980s. As an administrative unit, the commune was replaced by the township, and the production brigade under the commune was replaced by the village committee. The 1982 Constitution defines the village committee as a self-governing body of villagers (Clause 111). Except in a few localities, committee members were appointed, rather than elected. In 1987, under the leadership of chairman Peng Zhen, the NPC passed a tentative version of the OLVC requiring that the village committee be elected, triggering elections in Chinese villages. By 1994, half of the Chinese villages had begun elections. By 1997, 25 of the 31 mainland provinces had adopted a local version of the OLVC, and 80 per cent of villages had introduced elections (Ministry of Civil Affairs 1998). In 1998, the formal version of the OLVC was passed by the NPC and elections have since spread quickly to almost all villages.

The village committee is comprised of three to seven members depending on the size of the village. The core members are the chairman, vice-chairman and accountant. Before 1998, candidates for the chairmanship were usually appointed 
by the township government, although popular nomination-a mixture of government appointment and popular nomination-and nomination by villager representatives also existed. The formal version of the OLVC requires that candidates be nominated by villagers, and the minimum number of villagers to propose a candidate is 10. A primer is held to reduce the number of candidates to two, and the formal contest is run between these two. This version of election is popularly called hai-xuan. Since 1998, hai-xuan has become increasingly popular. The term of the committee is three years, however, no limit is required.

Village elections in China operate in a weak institutional environment. In a typical village, the elected committee faces two major challenges that might hinder its ability to serve the will of the villagers. The first is its relationship with the Communist Party committee in the village. Despite the fact that the party committee is not popularly elected, the OLVC stipulates that the village committee work under the leadership of the party committee, reflecting the nature of China's one-party system. Since the party secretary is appointed by the higher authority, they often pursue an agenda different to that of the village committee. Backed by popular votes, however, the chairman of the village committee often defies the direction of the party secretary, although the result of the contest is not always in their favour (Oi and Rozelle 2000; Guo and Bernstein 2004). To reconcile conflict between the village committee and the party secretary, the central government has begun to encourage the latter to run for the village committee chairmanship in elections. While this will ease the tension inside the village (Guo and Bernstein 2004), the village committee still needs to face a second challenge, which comes from above.

Since village elections operate in an authoritarian institutional environment, where the upper-level governments - the township and county governments in particularare not elected and often intrude in village elections and other village affairs, the effectiveness of such elections to serve the will of the villagers has been called into doubt. Evidence shows that informed local people tend not to trust elections. For example, in a survey conducted in Fujian Province, Zhong and Chen (2002) found that it was the villagers who had low levels of internal efficacy and democratic values who were more likely to participate in an election, and those with higher levels of internal efficacy and democratic orientation stayed away from elections due to their awareness of the institutional constraints placed on the process.

The above two challenges raise the question of whether elections enhance the village committee's accountability to the local population. This issue is compounded by the possibility of elite capture inside the village. Bardhan and Mookherjee (2005) found that in India, decentralisation could lead to elite capture at the local level if the financing of public goods provision was not designed properly. In the 
context of the Chinese village, rising business elites have been found frequently to dominate village elections (Liu et al. 2001). Although there are no a priori reasons to believe that business élites would necessarily steer the village committee towards adopting pro-rich policies, this belief lingers within Chinese academia and policy circles. In addition, lineages have regained their strength and frequently serve as vehicles for the expression of political interests in elections (see Liu et al. 2001 for a case study). There is concern that the revitalisation of lineages will distort the results of village elections.

\section{Data and descriptive evidence}

The data for this study comes from two sources. One is the Fixed-Point Survey (FPS) maintained by the Research Centre of Rural Economy, the Ministry of Agriculture, and the other is a retrospective survey conducted by the author in the spring of 2003. The FPS started in the early 1980 s and has maintained a survey frame of about 340 villages and 30,000 households in all Chinese continental provinces. A strong feature of this is that it surveys a relatively large number of households (50-100) in a village, allowing, for the purposes of this study, a calculation of the Gini coefficient in a village with a fair degree of accuracy. Village-level data of 48 villages in eight provinces for the period 1986-2002 was obtained for this study. ${ }^{2}$ These eight provinces were Guangdong, Zhejiang, Hunan, Henan, Sichuan, Gansu, Shanxi and Jilin. They cover diverse geographic settings and income levels. The 2003 retrospective survey provides information on village elections in the 48 villages. The household sample is smaller than the FPS sample. The FPS does not have a good record of the household codes, instead the study uses household characteristics to match households in order to establish the panel structure, resulting in a smaller sample, with 1,118 households left for household-level analysis. In addition, the starting year for household data is 1987 instead of 1986 .

The village election

As the first election is likely to have more dramatic impact than subsequent elections, the focus is on studying the impact of the first election. Figure 13.1 presents the number of elections in villages and their accumulative percentage in each year. The year 1987 was the start of village elections in China and 12 of the sample villages had their first election in that year. By 1990, more than 50 per cent of the sample villages had at least one election and, by 2002, only one village had not had an election (it is a remote village in Gansu Province).

The introduction of elections had a clear regional pattern: villages in the same province tended to introduce elections in the same year that the province adopted 
Figure 13.1 Introduction of village elections in the sample villages, 19872002

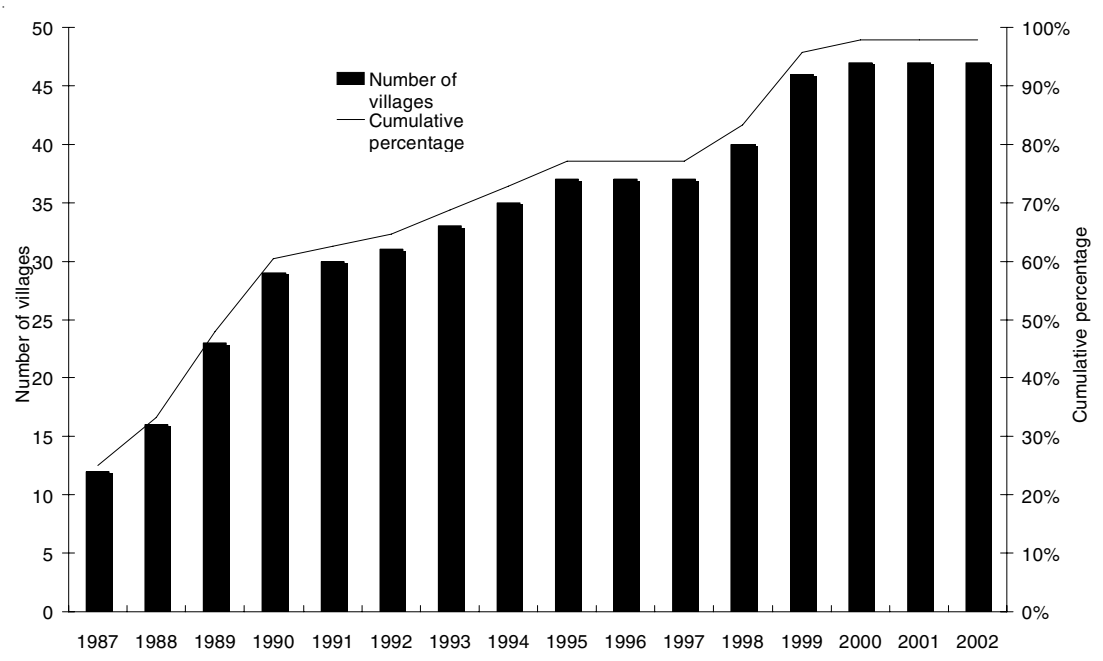

Source: Author's calculations.

the OLVC. ${ }^{3}$ Table 13.1 shows the year each sample province adopted the OLVC, as well as the median and standard deviation of the year of the introduction of elections in its villages. Except Guangdong, all other provinces adopted the OLVC in the period 1988-92. ${ }^{4}$ The median year of election was close to the year that the province adopted the OLVC, and the standard deviation was small in all provinces except Henan, Gansu and Shanxi, which had large standard deviations. ${ }^{5}$ The median year and the adoption year were quite close in Henan and Shanxi, but were far apart in Gansu (the election lagged well behind the adoption of the OLVC). Overall, there were great regional and time variations in the introduction of the first election. One such variation is especially pertinent to this study-that is, high-income and low-income villages were mixed in terms of the timing of the first election. The introduction of elections is an irreversible process, so if the timing of the first election is associated closely with income levels, it will be hard to distinguish between the true effects of elections and the effects of incomes. The mixed nature of the data removes this possibility. 
Table 13.1 First election in the sample villages and adoption of the OLVC in the sample provinces

\begin{tabular}{|c|c|c|c|c|c|c|c|c|}
\hline Year OLVC & Guangdong & Hunan & Zhejiang & Henan & Sichuan & Gansu & Shanxi & Jilin \\
\hline $\begin{array}{l}\text { adopted } \\
\text { Median year }\end{array}$ & 1998 & 1989 & 1988 & 1992 & 1991 & 1989 & 1991 & 1991 \\
\hline $\begin{array}{l}\text { of first election } \\
\text { Standard devia } \\
\text { of year of } \\
\text { first election }\end{array}$ & $\begin{array}{l}1999 \\
0.5\end{array}$ & 1988 & 1989 & 1991 & 1989 & 1995 & 1993 & 1989 \\
\hline
\end{tabular}

Source: Author's calculations.

\section{Village expenditure}

Public goods provision in rural China is a joint effort between various levels of government and the villages. For major projects that involve several villages (such as road-building), it is usually the case that one or several levels of government provide part of the funds and the targeted villages provide the rest. For smaller projects within a village, the village budget is usually fully responsible, although governments also provide some funds (Song 2004). Villages obtain their revenue from fees, profits from collective firms and rents for village properties. Fees are surcharges (the so-called san-ti-wu-tong in Chinese documents) designated specifically for local public goods provision and should be shared with the township government to provide public goods within the township territory. Seven types of village spending are recorded in the FPS: investment in village businesses, public expenditure, office maintenance, salaries for village committee members, revenue handed to the township government, other spending, and surplus/deficit. To study the accountability of the village committee, the study is concerned with public expenditure, office maintenance and village committee salaries. ${ }^{6}$ Public expenditure includes transfers to households and spending on public projects such as local roads, schools, irrigation systems and healthcare facilities, which are likely to benefit the majority of villagers. In contrast, office maintenance costs are spent on the village government's daily operations and can easily become the prey of village committee members. Together with village committee salaries, maintenance costs have the opposite implication of public expenditure for the village committee's accountability. Consequently, I will add them together and call them 'administrative costs'. In the econometric exercises to be presented in the next section, I will 
study the shares of public expenditure and administrative costs in total village spending.

Figure 13.2 presents the trends of the two shares for the period 1986-2002. The share of public expenditure in village spending was remarkably stable, remaining just below 20 per cent for the entire sample period. In contrast, the share of administrative costs increased dramatically after 1993. By 2002, 43 per cent of total village spending was used to operate the village government, whereas the share was less than 20 per cent before 1993. These two time trends have an important implication for our tests of the role of elections. If we find that elections increase the share of public expenditure but reduce the share of administrative costs, we will obtain strong evidence to support the proposition that elections enhance the village committee's accountability because the effects of elections run against the time trends.

Income redistribution

Before the central government announced the abolition of agricultural taxes and fees in 2005, households paid fees (san-ti-wu-tong) to the village to finance village public projects and affairs. ${ }^{7}$ In villages with income from village-sponsored businesses (such as factories and land rentals), households also receive income transfer from the village. Figure 13.3 presents the trends of per capita fees, per capita income transfer and per capita net income transfer based on 1,118 households in the sample villages in the period 1987-2002. The amount of fees increased in the early 1990s but stabilised after 1995. The amount of income transfer was high in the early years but declined substantially over time. This might have a lot to do with the privatisation of collective enterprises in the 1990s. Net income transfer was kept positive in all the years.

\section{Gini coefficients}

The Gini coefficient is calculated on the per capita net income of the original FPS sample households (so each village has 50-100 households). Household net income is defined as household income net of operational costs and taxes but with transferred income from the government. We calculate the Gini coefficient for each village in each year. To take care of possible bias caused by household size, I weigh the calculation by household size, that is, I enter a household in the calculation by the number of its members. Figure 13.4 plots the average Gini coefficients of the 48 villages during 1987-2002. There was apparently an increasing trend of income inequality in the period, rising from 0.26 in 1987 to 0.28 in 1992 , and then to 0.32 in 2001 , decreasing slightly to 0.31 in 2002. This matches the 


\section{Figure 13.2 Shares of public expenditure and administrative costs in village spending, 1986-2002}

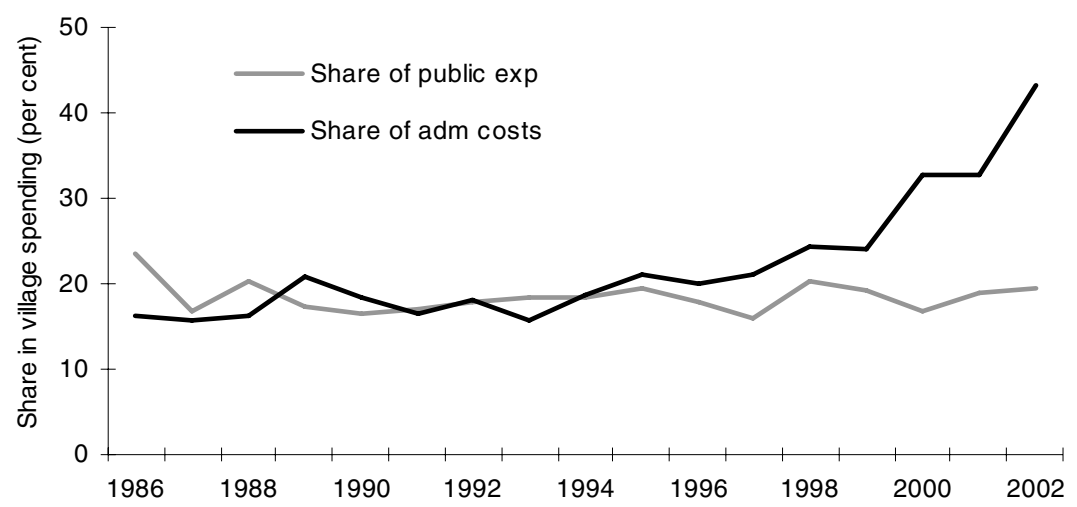

Source: Author's calculations.

Figure 13.3 Fees and income transfer, 1987-2002 (yuan)

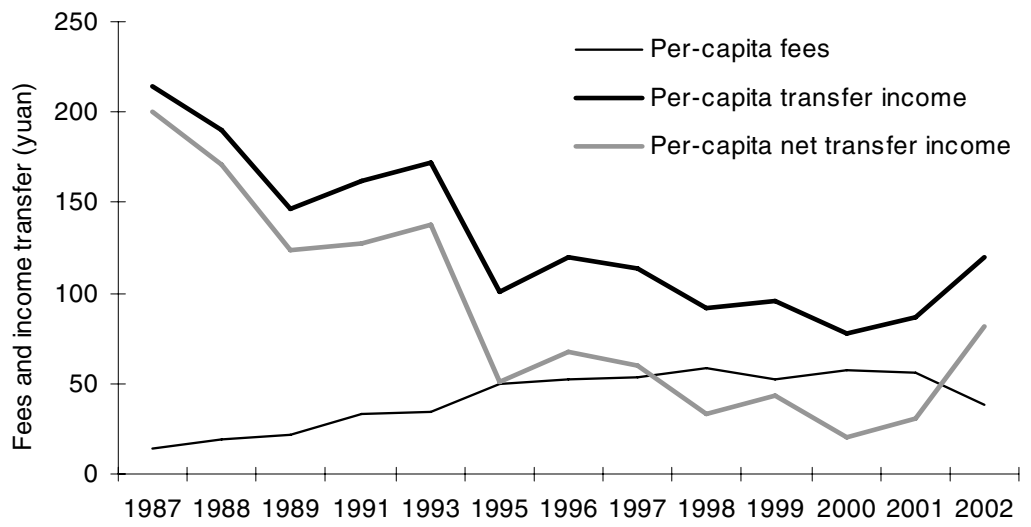

Note: Fees and income transfer are in 2002 yuan adjusted by the CPI published in China Statistical Yearbook. Data for 1990, 1992 and 1994 are missing.

Source: Author's calculations. 
Figure 13.4 Trend of the Gini coefficient in the sample villages, 1987-2002

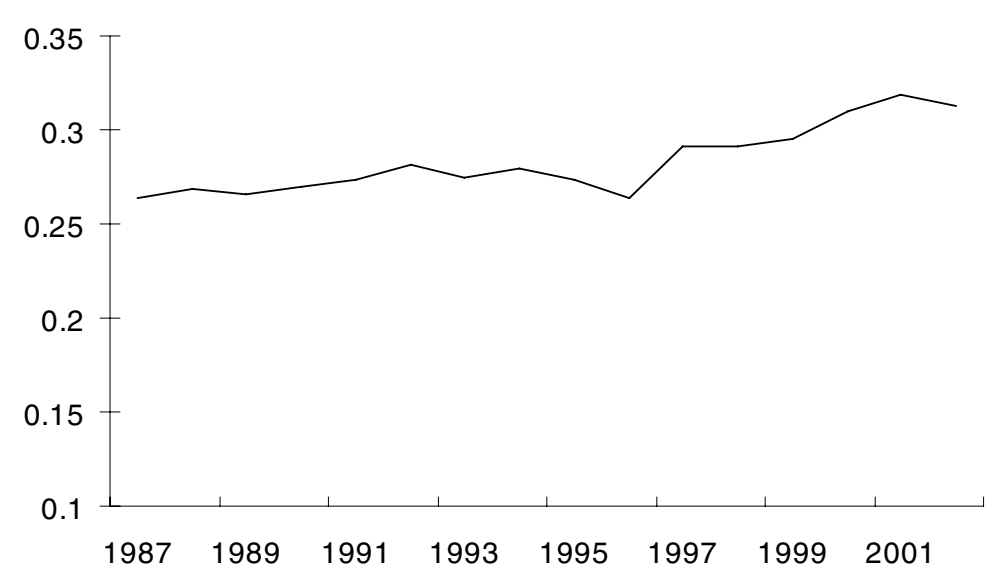

Source: Author's calculations.

national trend. The Gini coefficient in rural China increased from 0.29 in 1987 to 0.35 in 2000 (Riskin et al. 2002). ${ }^{8}$

Figure 13.5 provides the histograms of the Gini coefficients in 1987, 1999 and 2002. They largely agree with the histograms provided by Benjamin et al. (2005), who used a sample that contained my own. It is clear that income distribution was becoming more unequal. In particular, the distribution of 2002 dominates the distribution of 1987 by the first-order stochastic domination.

\section{Econometric results}

The study uses the two-way fixed-effect panel model for the estimations. This model allows us to control unobserved village or household characteristics and time events that might simultaneously determine the introduction of the election and the dependent variables. The main explanatory variable is a dummy variable indicating the introduction of elections. It is equal to zero if a village had not begun elections by a certain year, and equal to one if it had had at least one election. I will introduce the dependent and control variables when we study individual topics.

\section{Elections and accountability}

As indicated before, I study the share of public expenditure and the share of administrative costs in the total village budget for the effects of elections on the 


\section{Figure 13.5 Histograms of the Gini coefficients in 1987, 1999 and 2002}
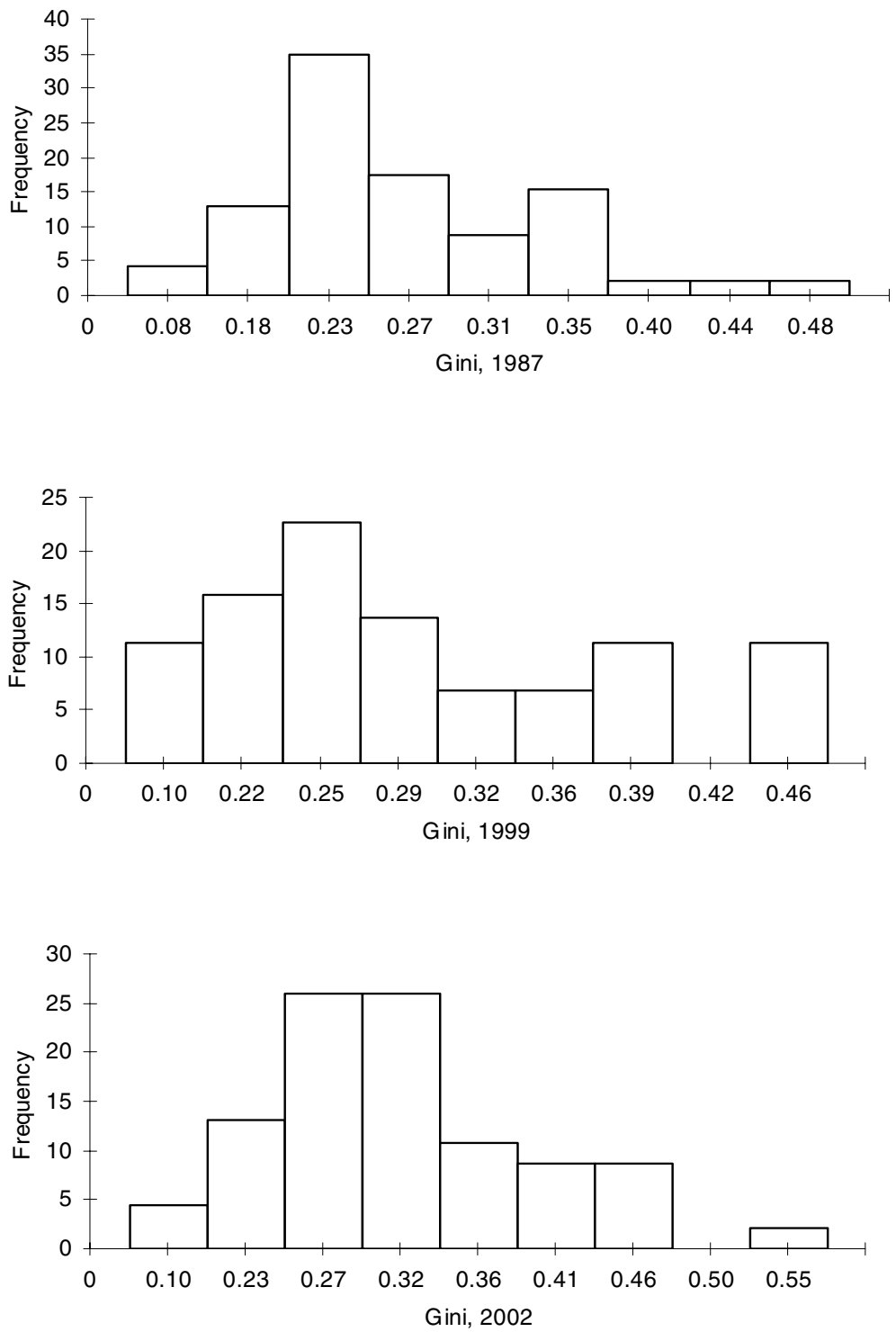

Note: The number for each bar in the figures is the average of the Gini coefficients represented by the bar.

Source: Author's calculations. 
accountability of the village committee. The data coverage is from 1986 to 2002 . The control variables include village population, per capita net income, the share of collective income in total village income, per capita land territory, the unemployment rate and the share of migrant workers who work outside the county. Village population (entering the regressions in logarithm terms) controls the village size. A larger population might make public decision-making more difficult so it would tend to have a negative effect on village governance. Per capita net income (converted into 2002 yuan and entering the regressions in logarithm terms) controls the level of economic development of a village, and the share of collective income in total village income controls the relative size of the collective economy. Studies frequently find that people in villages with higher incomes or a larger collective economy are more likely to participate in village elections, presumably because the stakes are higher in these villages (Hu 2005). Per capita land territory is introduced to represent the amount of resources that a village possesses. Land resources are particularly important in the coastal provinces, as fast growth of the local industry has significantly raised the demand for land. Recent literature suggests that natural resources can be a curse for a country, as they tend to lead to easier elite capture (Hoff and Stiglitz 2004). It is thus interesting to see whether a larger territory reduces a village government's accountability in our case.

Table 13.2 presents the results. Two regressions are run for each dependent variable, one with and one without any control variable. The first regression provides the estimate for the total effect of elections, and the second provides the estimate for a marginal effect. For the share of public expenditure, the total and marginal effects are statistically significant. ${ }^{9}$ They are also meaningful economically as they are equivalent to 22.8 per cent and 26.4 per cent respectively of the average share of public expenditure in the sample. For the share of administrative costs, the total effect of elections remains statistically significant. The introduction of elections reduces administrative costs by about 4 percentage points, which is equivalent to 18.2 per cent of the sample mean. The marginal effect, however, turns only weakly significant (the $p$-value is 0.12 ). This shows that the positive effect of elections on administrative costs is through the impact on the control variables.

The above results are very strong in terms of the two time trends shown in Figure 13.2. The share of public expenditure was stable, so the result-that elections increase this share-is not an artefact of the time trend. In the case of the share of administrative costs, there was even a significant upward trend, so the result-that elections reduce the share-goes against the time trend. 


\section{Table 13.2 The effects of elections on public and administrative expenditure}

\begin{tabular}{|c|c|c|c|c|}
\hline \multirow[b]{2}{*}{ Variables } & \multicolumn{2}{|c|}{ Share of public expenditure } & \multicolumn{2}{|c|}{ Share of administrative costs } \\
\hline & $\mathrm{R} 1$ & $\mathrm{R} 2$ & R3 & $\mathrm{R} 4$ \\
\hline Constant & $15.67^{* * *}(1.52)$ & $-11.79(52.72)$ & $24.75^{* * *}(1.31)$ & $-14.76(45.46)$ \\
\hline Election dummy & $4.21^{* *}(2.13)$ & $4.87^{*}(2.14)$ & $-3.96^{* *}(1.83)$ & $-2.80(1.84)$ \\
\hline Ln (population) & & $3.59(7.44)$ & & $5.77(6.42)$ \\
\hline \multicolumn{5}{|c|}{ Ln (per capita income) } \\
\hline (‘000 yuan) & & $-1.65(1.62)$ & & $2.14(1.40)$ \\
\hline $\begin{array}{l}\text { Share of collective } \\
\text { total income (per c }\end{array}$ & $\begin{array}{l}\text { income in } \\
\text { ent) }\end{array}$ & $-0.14^{* * *}(0.05)$ & & $-0.14^{* * *}(0.04)$ \\
\hline $\begin{array}{l}\text { Per capita land } \\
\text { territory (mu) }\end{array}$ & & $0.55^{\star \star \star}(0.15)$ & & $-0.43^{* * *}(0.13)$ \\
\hline $\begin{array}{l}\text { Unemployment } \\
\text { rate (per cent) }\end{array}$ & & $-0.46(0.98)$ & & $-0.38(0.85)$ \\
\hline $\begin{array}{l}\text { Share of migrant } \\
\text { workers (per cent) }\end{array}$ & & $0.03(0.05)$ & & $-0.02(0.05)$ \\
\hline Adjusted $\mathrm{R}^{2}$ & 0.26 & 0.28 & 0.44 & 0.45 \\
\hline
\end{tabular}

Notes: ${ }^{*}$ significant at the 10 per cent significance level ** significant at the 5 per cent significance level ${ }^{* \star *}$ significant at the 1 per cent significance level

The regressions are based on data from 48 villages in the period 1986-2002, and the total number of cases is 806 . All the regressions use the panel model with village and year fixed effects. Standard errors are in parentheses.

Source: Author's calculations.

\section{Income redistribution}

Data is used from 1,118 households in the period 1987-2002 to study the net and total income transfer. In the regressions, there are sets of control variables. One set is comprised of household variables including relative per capita earned income (RELINC), per capita land, per capita productive assets, average age, average education of family labour, male ratio, five dummies indicating whether a family has a member working in a government agency other than the village council, working in the village council, being a Communist Party member, with a regular wage job, and in the army, and a dummy indicating whether a family is a designated wubaohu, that is, a household receiving welfare from the village. Earned income is the income earned by the household in agricultural production, business and labour hiring. The study divides the per capita earned income by the village average income in each year to obtain the relative per capita earned income. This variable is included in the regressions to control for a household's relative position in the 
village. Its coefficient reflects the progressiveness (if it is negative) or regressiveness (if it is positive) of income redistribution. The other family attributes control for the factors that might affect the amount of fees paid by a household and the amount of income transfer received by it. The other set is comprised of the village variables that were used in Table 13.2. This set of variables controls for village characteristics.

The estimation results are presented in Table 13.3. Four regressions are performed. R1 and R2 study per capita net income transfer, and R3 and R4 study per capita total income transfer. R2 and R4 include the interaction term between RELINC and the election dummy, whereas R1 and R3 do not. The results are generally consistent with expectations. Income redistribution is progressive. A household that is richer, has more land or assets or has at least one regular wage earner, receives less net income transfer; on the other hand, a wubaohu and a household with a member in the army receives more net income transfer. The progressiveness of the total income transfer is, however, not as strong as the net income transfer. The somewhat surprising result is that households with a village cadre receive significantly less net and total income transfers. This shows that, on average, village cadres are not taking advantage of their position in receiving documented income from the village. ${ }^{10}$

R1 and R3 provide the estimates for the election dummy's average effects on the net and total income transfer. Neither is statistically significant, so village elections do not increase income redistribution. By adding the interaction term between RELINC and the election dummy, R2 and R4 tell us how village elections change the progressiveness of income redistribution. The coefficient of the interaction term is positive in both regressions, and, surprisingly, they are both positive. This means that elections have reduced the progressiveness of income redistribution. By the estimate provided in $\mathrm{R} 2$, in a village without elections, a household receives 114 yuan less of net income transfer for each of its members if its income is twice the village average. Elections close this gap by 86 yuan. The effect of elections is even stronger for the total income transfer, in which case the gap is reduced by 107 yuan. The commune system in Chinese villages had a long history, so villages' income redistribution had been quite progressive before any elections happened. To the extent that it empowers not just the poor, but the rich, the village election can lead to less progressive income redistribution.

Income inequality

To study the impact of elections on income inequality, I have run four regressions on the Gini coefficient that were obtained in the previous section. In the first 
The Turning Point in China's Economic Development

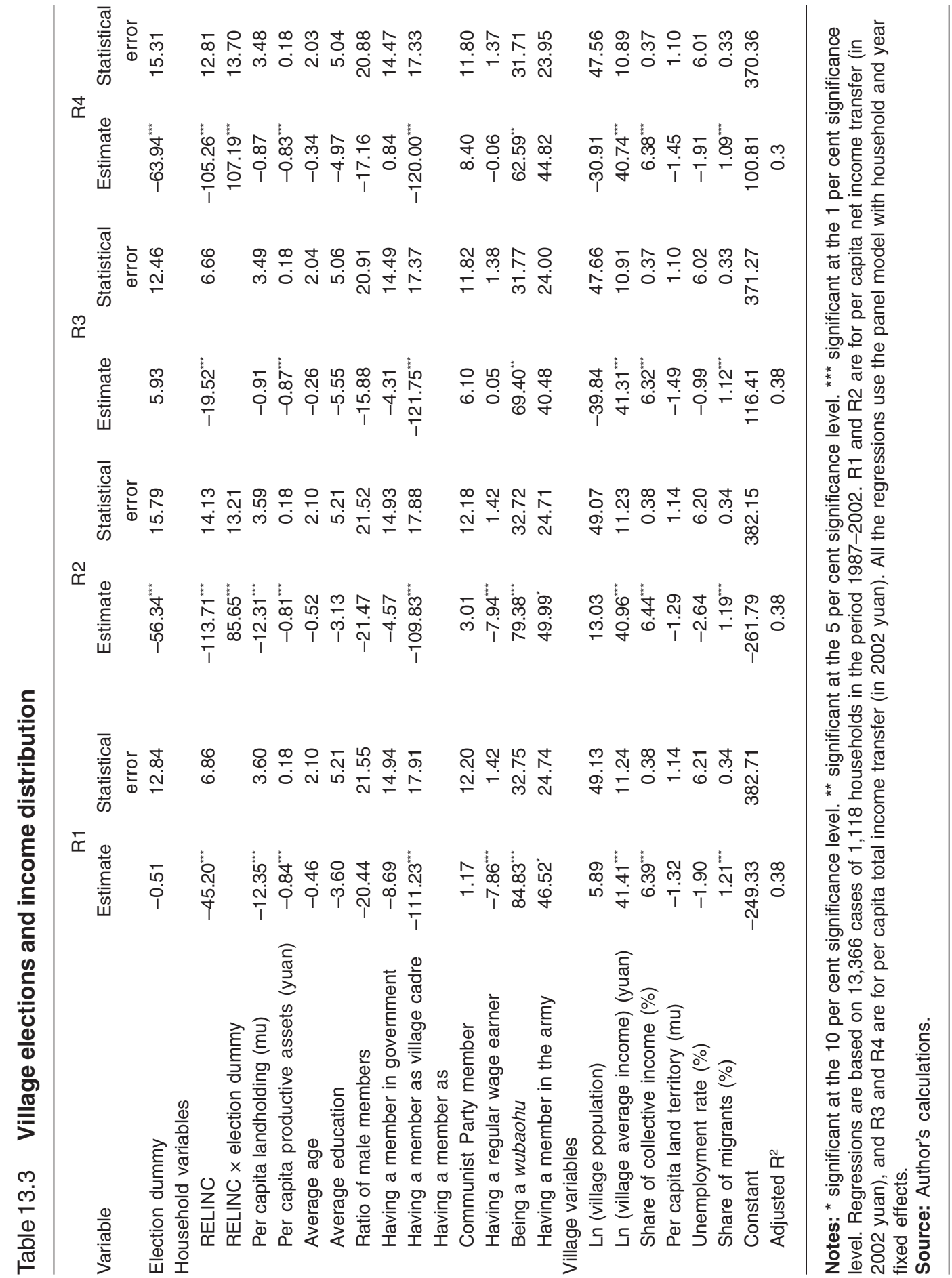


regression, the results of which are presented in R1 of Table 13.4, I include only the election dummy and control the village and year fixed effects, so this regression provides us with the estimate for the election's total effect. It is shown that an election reduces the Gini coefficient by 0.016 and this effect is significant at the 1 per cent significance level. It is equivalent to 5.7 per cent of the sample average of 0.28 , but is 32 per cent of the Gini coefficient's increase in the period 19872002. This is a large effect. In particular, it is obtained against the growth trend of the Gini coefficient.

In the other three regressions, I have included different sets of control variables to obtain different estimates for the marginal effect of the village election. R2 adds village per capita income, its square and the logarithm of village population. The two income variables are added to represent the Kuznets Curve that is frequently studied in the literature. The coefficient of the election dummy has remained essentially the same as in $\mathrm{R} 1$ and it is still significant at the 1 per cent significance level. The Kuznets Curve is verified. In addition, a larger village tends to have a larger Gini coefficient.

R3 then adds the other village variables that I used before-the share of collective income in total village income, per capita land territory, the unemployment rate and the share of migrants. Now the coefficient of the election dummy becomes barely significant (the $p$-value of the t-statistics is 0.12 ) and its magnitude becomes smaller. The three old control variables remain significant. Among the new control variables, only the share of collective income has a significant coefficient. An increase of 1 percentage point of the collective income would reduce the Gini coefficient by 0.008 , which is a very strong effect. The average of the share of collective income is 6.8 per cent in the sample, and the standard deviation is 15.2 per cent, so there are wide variations in the data. If the share of collective income increases by one standard deviation, the Gini coefficient will decrease by 0.122 .

$\mathrm{R} 4$ further adds four coefficients of variations (CVs) to the regression, which are those of household size, household average education of adult members, per capita household landholding and the number of regular household wage earners. These four CVs are meant to capture the variations that have impacts on the Gini coefficient and, in the meantime, are possibly correlated with the election. The previously significant control variables are still significant. Among the new control variables, the $\mathrm{CV}$ s of household size and household wage earners are significant and increase the Gini coefficient, which is an understandable result. The election dummy has, however, become highly insignificant.

The above results show that the village election has a significant effect to reduce income inequality, and this is channelled mainly by increasing village 


\section{Table 13.4 Village elections and income distribution}

\begin{tabular}{|c|c|c|c|c|}
\hline & R1 & $\mathrm{R} 2$ & R3 & R4 \\
\hline \multirow[t]{2}{*}{ Election dummy } & $-0.016^{* * *}$ & $-0.015^{* *}$ & -0.010 & 0.001 \\
\hline & $(0.006)$ & $(0.006)$ & $(0.006)$ & $(0.006)$ \\
\hline & $0.197 \mathrm{E}-2^{* * *}$ & $0.150 \mathrm{E}-2^{* *}$ & $0.167 \mathrm{E}-2^{* *}$ \\
\hline \multicolumn{2}{|c|}{ ('000 yuan) } & $(0.630 \mathrm{E}-3)$ & $(0.631 E-3)$ & $(0.606 \mathrm{E}-3)$ \\
\hline \multicolumn{2}{|l|}{ Per capita net } & $-0.307 \mathrm{E}-4^{*+*}$ & $-0.248 E-4^{* * *}$ & $-0.288 \mathrm{E}-4^{*}$ \\
\hline \multicolumn{2}{|l|}{ income squared } & $(0.679 \mathrm{E}-5)$ & $(0.681 \mathrm{E}-5)$ & $(0.657 E-5)$ \\
\hline \multirow{2}{*}{\multicolumn{2}{|c|}{ Log village population }} & $0.058^{* * *}$ & $0.057^{* * *}$ & $0.050^{* * *}$ \\
\hline & & $(0.021)$ & $(0.021)$ & $(0.020)$ \\
\hline \multirow{2}{*}{\multicolumn{3}{|c|}{ Share of collective income (per cent) }} & $-0.794 \mathrm{E}-3^{*+*}$ & $-0.768 \mathrm{E}-3^{*+*}$ \\
\hline & & & $(0.151 \mathrm{E}-3)$ & $(0.145 E-3)$ \\
\hline \multirow{2}{*}{\multicolumn{3}{|c|}{ Per capita land territory (mu) }} & $-0.385 E-3$ & $-0.115 \mathrm{E}-3$ \\
\hline & & & $(0.457 \mathrm{E}-3)$ & $(0.446 \mathrm{E}-3)$ \\
\hline \multirow{2}{*}{\multicolumn{3}{|c|}{ Unemployment rate (per cent) }} & $0.127 \mathrm{E}-4$ & $-0.479 \mathrm{E}-3$ \\
\hline & & & $(0.269 E-2)$ & $(0.259 E-2)$ \\
\hline \multicolumn{3}{|c|}{ Share of migrants (per cent) } & $0.133 \mathrm{E}-4$ & $-0.500 \mathrm{E}-4$ \\
\hline & & & $(0.168 \mathrm{E}-3)$ & $(0.167 E-3)$ \\
\hline \multirow{2}{*}{\multicolumn{4}{|c|}{ Coefficient of variation of household size }} & $0.166^{* *+*}$ \\
\hline & & & & $(0.032)$ \\
\hline \multicolumn{4}{|c|}{ Coefficient of variation of average } & -0.006 \\
\hline education of hou & \multicolumn{3}{|c|}{ education of household adults } & $(0.035)$ \\
\hline \multicolumn{4}{|c|}{ Coefficient of variation of per } & -0.007 \\
\hline \multicolumn{4}{|c|}{ capita household landholding } & $(0.005)$ \\
\hline \multicolumn{4}{|c|}{ Coefficient of variation } & $0.013^{*+*}$ \\
\hline \multicolumn{4}{|c|}{ of household wage earners } & $(0.002)$ \\
\hline \multirow[t]{2}{*}{ Constant } & $0.266^{* * *}$ & -0.124 & -0.111 & -0.153 \\
\hline & $(0.007)$ & $(0.151)$ & $(0.149)$ & $(0.144)$ \\
\hline Adjusted $\mathrm{R}^{2}$ & 0.662 & 0.677 & 0.689 & 0.715 \\
\hline
\end{tabular}

Notes: * significant at the 10 per cent significance level. ** significant at the 5 per cent significance level. ${ }^{* \star}$ significant at the 1 per cent significance level. The regressions use data from 48 villages in the period 1987-2002. The number of observations is 706 . Both regressions use the panel model with village and year fixed effects. Standard errors are in parentheses.

Source: Author's calculations. 
collective income, creating wage jobs or changing the distribution of land. With more collective income, the elected village committee can engage in more income redistribution and public investment. However, our early study of the net and total income transfer shows that the election has not increased income redistribution. Therefore, its positive effect to reduce income inequality must come from greater public investment. The creation of wage jobs in many cases is also tied to the growth of the collective income. In the past, village-run enterprises were the main source of village-generated jobs. In the past decade, most collective enterprises have been privatised and collective income now comes mainly from land and building rentals to outside investors who set up factories on village land. With more such investors coming in, the number of jobs in the village increases. Finally, the village committee can redistribute land to ensure it is held more equally among the households. According to the Constitution, land is owned collectively by villagers, so each villager has an entitlement to village land (Liu et al. 1998). This provides the legal basis for the village committee to undertake land redistribution.

\section{Conclusions}

The village election has been a significant step for China in a move towards full democracy. Using a unique panel data set, this study finds that elections have played a significantly positive role in enhancing the accountability of village committees and have reduced income inequality in villages. I have further found that elections have not led to more redistributive policies. Therefore, the positive impact of elections on income inequality is not brought about by more income redistribution, but by more public investment. These results have significant implications for the current debate in China and the developmental literature in general.

First, the results show that grassroots democracy can work even in a distorted institutional environment. It appears that village elections have only created numerous isolated democratic islands because above the village are the township and county governments- that do not draw their mandates from elections. These two upper-level governments still intervene in village affairs, either through direct orders or through the party secretary inside the village. In some cases, the upperlevel governments intervene directly in a village election to make sure that the people who they favour are elected. These people then care more about their image in the eyes of the higher-level governments than they do about villagers' 
voices. The results of the study show, however, that on average, elections have made the elected village committee more accountable to villagers. Indeed, the elected village committee often uses the mandate created by an election to defy the directives of the party secretary and sometimes of the higher authorities (see Liu et al. 2001 for an example). Recent interest in the literature is to study how democracy works in a less institutionalised environment (Acemoglu 2005). The results provide one piece of evidence for this literature: as long as people are empowered, so that the threat of being voted out of office is real for village leaders, elections can work even in a distorted institutional environment.

Second, the results also show that villagers can quickly learn how to run a functioning democracy. At least at the introduction of village elections, many people had doubts about farmers' capabilities to run a successful democracy in China. These kinds of doubts have been diminishing recently, but there are still those who doubt whether the experience of the village election can be transplanted to higher-level governments. At the other extreme, there are people who believe that only the direct election of government officials can be accepted as true democracy. A compromise might be the direct election of delegates to the local and national People's Congress because this would not require a radical change of the Constitution, but, at the same time, it would enhance the accountability of local governments.

Third, the finding that village elections have not led to more income redistribution, but have improved equality defies the conventional wisdom that democracy leads to more distributive policies (Alesina and Rodrik 1994; Benabou 1996). This might be related to the small scale of the village election. Within the village setting of lineage and other intimate ties, it might be easier for villagers to reach more productive decisions than to fight for short-term redistributions. My finding might, however, still be indicative of larger-scale democracies.

\section{Acknowledgments}

I am grateful for financial support from the Chinese Medical Board and the National 211 Projects Fund and thank the excellent data collection efforts provided by the Research Centre of Rural Economy, the Ministry of Agriculture, People's Republic of China. Dwayne Benjamin, Loren Brandt and John Giles shared some of their data; Mengtao Gao, Ang Sun, Shuna Wang and Shenwei Zhang provided excellent research assistance; Yan Shen contributed to part of the research. I thank all of them for their help and generosity. 


\section{Notes}

1 For a recent and comprehensive study, see Milanovic and Ying 2001 and the references therein.

2 The FPS did not conduct the survey in 1990, 1992 and 1994. We fill up the village-level data of these years by the average of the nearest two years, but leave the household data intact.

3 When the NPC passes a law that involves government action, each province enacts a local law that specifies the details of the implementation of the central law. It is noteworthy that most provinces adopted the OLVC even when it was in the experimental stage.

4 Guangdong adopted the OLVC in 1999. Before then, the province did not treat the village as a self-governing administrative unit, but rather as a delegated branch of the township government. This is why it had not adopted the law.

5 Notice that in Hunan, Henan, Sichuan and Jilin, the median year of the first election was earlier than the year of adopting the OLVC. It seems that these provinces waited for some experiments to provide the implementation details of the law.

6 The relationship between investment in village businesses and accountability is unclear. In many cases, village businesses are either pet projects or pork-barrels for village leaders. However, they can also benefit the villagers if the village committee is relatively clean.

7 After the abolition, villages had to get approval from the village conference to finance local public projects on a case-by-case basis.

8 It is understandable that the national Gini coefficients were larger than those in our sample villages because the latter are calculated within a much smaller

9 The fact that the marginal effect is larger than the total effect shows that there are correlations between elections and the control variables and these correlations reduce the impact of elections on the dependent variable.

10 My results do not tell us whether village cadres receive under-the-table income from the village. 